\title{
Enlightenment and Counter-Enlightenment in Spanish America. Debating Historiographic Categories
}

Roberto Breña and Gabriel Torres Puga

HCM 7: 344-371

DOI: $10.18352 / \mathrm{hcm} .562$

\begin{abstract}
This article gives an overview of the historiographic revolution that the study of the Enlightenment has gone through in the last fifteen years in the Western world and assesses part of the recent bibliography on the Spanish and Spanish American Enlightenments. It is also a critical analysis not only of Jonathan Israel's perspective on the Spanish American Enlightenment, but mainly, in a more general sense, of the a-critical application of the categories 'Enlightenment' and 'CounterEnlightenment' to Spain and, particularly, to the Spanish American case. As the Spanish American Enlightenment shows, this was a social and intellectual process with a series of peculiarities or specificities that complicate the indiscriminate application of the aforementioned categories. A critical review of Israel's interpretation of the Spanish American Enlightenment and especially the ambiguous character of the Spanish American Counter-Enlightenment brings to the fore the need for a more subtle and profound debate on these issues.
\end{abstract}

Keywords: Age of Revolutions, Counter-Enlightenment, Enlightenment, Jonathan Israel, Spain, Spanish America, Spanish American independence movements 


\section{The Enlightenment Today}

For diverse reasons, during the last twelve or fifteen years the Enlightenment has received a level of attention in the Western world that seems to have no precedent. Be it the need to reinforce what this world represents in historical terms, or the urgency to recuperate a more positive vision of the Enlightenment, or, on the contrary, a sort of compulsion to show its weaknesses and contradictions, an important number of non-academic books have been published on the Enlightenment, its importance and its (positive and sometimes negative) legacy, since approximately 2005. ${ }^{I}$ Although specifically academic interest in the Enlightenment has a longer history (it dates back to the I990s), the debate that has predominated in Western academia since the beginning of this century is to a large extent a consequence of the works devoted to the Enlightenment by one single author.

In 200I, Jonathan Israel published Radical Enlightenment. Philosophy and the Making of Modernity, I650-I750, the first volume of what would become a trilogy on the Enlightenment. ${ }^{2}$ Considered as a whole, this is the most ambitious academic work that has ever been attempted on this intellectual, cultural and political movement. Fifteen years after the appearance of Radical Enlightenment, some aspects of Israel's oeuvre on the topic are in the process of becoming part and parcel of today's understanding of the period. However, the three books by Israel comprise a truly radical interpretation of the period and, as could have been expected, it provoked a stream of criticisms from many quarters. Israel's work on the Enlightenment is important in relation to Spanish America mainly for one reason: of all the authors that have specialized in the Enlightenment in general terms, he is the first one to pay close attention to the Enlightenment in Spanish America, to which he devotes a whole chapter in the last book of his trilogy. This means that many people will have contact with the Spanish American Enlightenment exclusively through Israel's lens. We will deal in some detail with this chapter later on, but first it is important to have an idea of some of Israel's main contentions about the Enlightenment.

For Israel, the European Enlightenment is an integrated intellectual and cultural movement, with differences from country to country, but dealing with the same intellectual problems and, very often, the same books. Therefore, for him the only valid framework to study the 
Enlightenment is as an international process. This first element could be positive to the extent that it permits him to revitalize the debate on the Enlightenment and to link academic works from several of the countries that represent the various Enlightenments that existed during the eighteenth century. More debatable, however, is the dualistic formula he applies to this international Enlightenment. For him, the Enlightenment consists of two clashing movements: what he calls the 'moderate mainstream Enlightenment' and what he terms the 'Radical Enlightenment' (Israel always writes the adjective with capital letters). The former is represented by figures like Newton, Descartes, Locke, Montesquieu, Voltaire, Hume and Kant; the latter, by Spinoza first and foremost, but also by authors like Bayle, Holbach, Helvétius, Diderot, Condorcet and Paine. This Radical Enlightenment, 'whether on atheistic or deistic basis, rejected all compromise with the past and sought to sweep away existing structures entirely, rejecting the Creation as traditionally understood in Judaeo-Christian civilization, and the intervention of a providential God in human affairs' ${ }^{3}$ Radical Enlightenment accepts only one philosophic basis: the one substance doctrine of Spinoza, which rejected any divine governance of the world and any compromise between philosophy and religion. This unity of substance, or monism, has consequences of the outmost importance for Israel and his view of the Enlightenment; among them, a purely rationalist perspective on human affairs and an intransigent materialism.

In Israel's view, there is a correspondence between Spinoza's philosophic monism and a radical political position: philosophic radicalism, characterized by 'unmistakably republican, even democratic tendencies'. ${ }^{4}$ Ten years later, his perspective was even more radical; these tendencies had turned into a full-blown democratic stance: 'By I789, radical thought and its social and legal goals had indeed come to form a powerful rival "package logic" [rival, that is, to the moderate mainstream] - equality, democracy, freedom of the individual, freedom of thought and expression, and a comprehensive religious toleration - that could be proclaimed as a clearly formulated package of basic human rights.' 5 In fact, the Radical Enlightenment that Israel develops in Democratic Enlightenment, the last book of the trilogy, is a group of authors that claim for an extended freedom in all domains of life and reject any kind of inequality, be it political, social, racial or gender-wise. 
From Israel's perspective and contrary to what many authors have claimed, the Radical Enlightenment was not a peripheral movement, but a fundamental development in many parts of Europe. He propounds that it acquired a hegemonic position in the I780s and I790s. This hegemony, nonetheless, was a fleeting moment: by 1792 Robespierre and the Jacobins had, in his own words, "rejected and perverted" the Radical Enlightenment. ${ }^{6}$ The reference to the French Revolution leads us to another distinctive aspect of Israel's interpretation of the Enlightenment: the direct causality that he establishes between the Radical Enlightenment and the several revolutions that took place in Europe and America during the 'Age of Revolutions'. He states that a correct understanding of the Radical Enlightenment is impossible without overturning 'almost' the whole current historiography of the French Revolution, 'which puts far too much stress on alleged institutional and social factors ... what I am arguing is that the Radical Enlightenment and not the Enlightenment as such - is the only important direct cause of the French Revolution understood as a total transformation of the political, legal, cultural, and educational framework of French life, administration, and society'. ${ }^{7}$

By itself, this proposition can be contrasted with the vast bibliography that in the last decades has changed our notion of one of the most intractable issues in intellectual history: the hyper-complex links that exist between ideas, intellectuals and books, on the one hand, and political practices, political events and political movements, on the other. Intellectual historians as renowned as Isaiah Berlin, to whom we will come back in the next section, have made us think that links of this type can be established without much difficulty and that, for example, the doctrines of arch-conservative French thinkers Joseph de Maistre (I753-I82 I) and Louis de Bonald (I754-I840) 'duly inspired' fascism and the other totalitarian doctrines of the twentieth century. ${ }^{8}$ At times, it appears as if Israel is opposed to this intellectualization of history, like when he says that contemporary political and socioeconomic developments are the 'real' and 'important' social context that intellectual historians should be relating ideas to. At the same time, he rejects cultural interpretations of the Enlightenment, like the ones that reputed historians like Robert Darnton and Roger Chartier have put forward since the I980s. ${ }^{9}$ However, when it comes to explaining the origins of revolutions, the only dissemination that counts for Israel is 
the one of intellectuals with clear and articulated ideas. As if to dispel this contention, which runs through his whole vision of the Radical Enlightenment, he writes that no sensible historian proposes a 'decisive' spread of philosophical ideas among the general population, for these ideas never spread broadly. Nevertheless, he immediately adds: 'But they do sometimes penetrate where it counts.'

\section{The Counter-Enlightenment}

The prefix 'counter' applied to certain historic categories, like 'CounterRenaissance' or 'Counter-Reformation', had been in use for some time when the term 'Counter-Enlightenment' was first used by Isaiah Berlin in the now famous eponymous entry which first appeared in the Dictionary of the History of Ideas edited by Philip P. Wiener in I973. ${ }^{I I}$ However, it started to become well-known when it was republished in I979 in what is one of the most famous anthologies of Berlin's essays: Against the Current (Essays in the History of Ideas). As James Schmidt has demonstrated recently, while Berlin was not the first one to use the term 'Counter-Enlightenment', he was the first one to delve into it and he was also responsible for its diffusion in the Western academic world. ${ }^{12}$

At present, there is an agreement among some of the most important analysts of the period in the sense that Berlin's conception of the Enlightenment presented in his seminal text on the CounterEnlightenment is a simplification or even a 'fabrication' (to use Schmidt's term). In the text, Berlin gives a list of what he considers 'the central principles of the Enlightenment': universality, objectivity rationality, the capacity to provide permanent solutions to all genuine problems of life or thought, and the accessibility of rational methods to any thinker armed with adequate powers of observation and logical thinking. ${ }^{13}$ At present, it seems evident that this vision of the Enlightenment is, at least, partial. Especially in one sense: it is not difficult to see that with his understanding of the Enlightenment Berlin was creating a historical period and an intellectual movement that enabled him to give more substance and entity to the voice of the dictionary entry he was contributing to: the Counter-Enlightenment. As Zeev Sternhell has shown, Berlin reads the Enlightenment through the eyes of some of its most 
decided critics (Herder, Burke and De Maistre among them). In this respect, Sternhell poses a question that seems pertinent: 'Need it be pointed out here that the thinkers of the Enlightenment never reduced the complexities of human life to a single formula that could be found whenever needed?' ${ }^{14}$

The point we are trying to make here is that since its very inception the concept 'Counter-Enlightenment' presented a series of problems that have to be taken into consideration before using the category and apply it to different contexts. The step is also daring because, most evidently, 'Counter-Enlightenment' is a pre-eminently negative category; that is, its substance depends on the category to which it is opposed. Moreover, no other Enlightenment was as critical vis-à-vis the Church and certain religious practices and ceremonies as the French Enlightenment. To take it as the measuring rod to apply the concept Counter-Enlightenment to other historical realities is a heuristic decision that may obscure the specificities of certain national contexts.

Up to now, we have said almost nothing about the different European and non-European Enlightenments. McMahon, in the introduction to his Enemies of the Enlightenment, writes that if there was a French Counter-Enlightenment, there should be several others. "These other Counter-Enlightenments await their historian." 15 Does that mean that every Enlightenment has its "Counter-Enlightenment"? It may be a matter of time before historians from the different countries carry out the research and the historiographic work that will enable them to talk, without hesitation, of this or that 'Counter-Enlightenment'. In the same logic, this could be the case with Spanish America; however, considering all the provisions that will be mentioned in the third section, from our perspective this is an open question.

One last issue: the religious essence of the discourse of the French Counter-Enlightenment. For all their exponents, religion was the cement of society, the main guarantee of social peace, the basis of education, the only legitimate ruler of daily life, the guarantor of afterlife and, in conjunction with the political apparatus but always above it, religion was the supreme power (because it was the supreme good). With terms used by contemporaries in Spanish-speaking countries, the Trono (throne) should always be subordinated to the Altar; not only in their time, but for all time. Faith, devotion, piety, veneration and absolute submission to revelation were the principles that guided 
all the Counter-Enlightenment authors. It was mainly prejudices or dispositions of the soul that were their guiding lights. They saw the philosophes as their sworn enemies, as the manifestation of evil and as the up-rooters of society. The discourse of the philosophes against the Church, their deism, their critical attitude towards traditional knowledge, their willingness to question prejudices of any kind, their tendency to put everything in question, and, finally, the open attitude of some of them in sexual matters were perceived by French CounterEnlighteners as a threat not only to French Catholic essence and history, but to Western civilization in general. Counter-Enlightenment discourse was not a matter of arguments; it was a matter of talking from a higher ground (literally), a matter of absolute refusal and disqualification, and, in the end, a matter of annulling the infidel, the deist or the atheist.

\section{Enlightenment in Spain and Spanish America}

The place of Spain in the European Enlightenment was for very long a debate that evolved mainly on how peripheral it was. ${ }^{16}$ Since the I990s, this tendency has changed, although we would argue that not in a radical way. ${ }^{17}$ One of the last books on the Spanish Enlightenment, a collection of essays edited by Jesús Astigarraga, has as one of its explicit objectives to 'put back' Spain on the Enlightenment map. This book accepts that the Ilustración (Spanish for Enlightenment) was 'moderate' in general and 'very moderate' in aspects like freedom of expression, transparency, public information and sociopolitical participation. ${ }^{18}$ In the most important book that has been published to date on the Iberian Enlightenments, Brian Hamnett not only studies the Spanish Enlightenment, but also the Portuguese, Brazilian and Spanish American cases. ${ }^{19}$ Coinciding with Astigarraga, he considers that moderation was a distinctive characteristic of the four Enlightenment processes just mentioned.

Astigarraga's book shows that in areas like political economy the Spanish ilustrados had something to say, that they developed ambitious regalist policies, that some of them initiated the creation of a 'public sphere' and that some others put in place scientific institutions or founded sociedades económicas in many parts of the Peninsula. Nevertheless, all of these efforts took place within an absolutist monarchy that was Catholic and confessional and that involved several 
forms of censorship, including that of the Inquisition, a long-standing and well-proven repressive machinery. At the same time, this monarchy was economically poor and commercially dependent. ${ }^{20}$ In other words, the Spanish Enlightenment evolved within a series of contextual elements that could be considered 'structural constraints'. If this was the case in the metropolis, it is natural to expect even more moderation in the case of the American colonies, that is, of the Spanish American Enlightenment. Once again, since modern historiography started to debate this Enlightenment, there have been doubts about its nature and entity. ${ }^{21}$ This is evident in the title itself of one of the first articles devoted exclusively to the topic: 'The dual role of Latin America in the Enlightenment', by Arthur P. Whitaker. ${ }^{22}$ Many years later, José Carlos Chiaramonte, responding to the question if there was true intellectual innovation in Ibero-America during the eighteenth century, gave the following answer: 'If by Ibero-American Enlightenment we should understand an original intellectual movement within the culture of that era, the answer should be negative. But the existence of an intellectual process that shares a series of orientations and foundations of the European Enlightenment is undeniable. ${ }^{23}$ In the next section, we will grapple with this issue considering some Spanish American authors of the eighteenth century.

Before doing that, it is important to devote some space to what could be considered an exception in contemporary historiography. As mentioned, none of the most reputed general interpretations of the Enlightenment had paid attention to Spanish America. This changed in 20I2, when Israel devoted a chapter to the region in his book Democratic Enlightenment. ${ }^{24}$ The thirty pages that Israel allots Spanish America have a revealing title: 'Philosophy and Revolt in Ibero-America, I765-I792'. As in the rest of his oeuvre, Israel wrote this chapter under the apparently inescapable logic of Radical Enlightenment versus Moderate Enlightenment. ${ }^{25}$ To begin with, Israel states that since the I740s the European Enlightenment 'exerted not just a profound but a profoundly disturbing impact throughout Spanish America' ${ }^{26}$ If, as it is the case, the Spanish American Enlightenment was influenced mainly by the Spanish one, it is difficult to reconcile the words just cited with what Israel writes only three pages ahead: 'Bourbon reformism in late eighteenth-century Spanish America was inspired by a style of Enlightenment thinking that was emphatically 
royalist, state oriented, Catholic, mercantilist, and deeply conservative in its views of social structure. ${ }^{27}$ At some point, Israel suggests a link between the revolutionary conscience that, in his view, starts to develop in Spanish America from I 770 onwards with the efforts that took place during those years to reform the universities of the region. However, at the same time he refers to the chronic disarray that Spanish American universities suffered due to the expulsion of the Jesuit order in 1767. Israel concludes that 'the universities had become engines spreading confusion, frustration, and dissatisfaction' ${ }^{28}$ It is here that he establishes a nexus between this dissatisfaction and the increasing number of creole families that sent their sons to Spain and other parts of Europe 'in appreciably larger numbers than before'. This statement is in evident tension with an aspect already alluded to: the increasing numbers of universities that were established in Spanish America since the I76os. In any case, this 'diaspora' had, according to Israel, unattended revolutionary consequences. It was the breeding ground for what he considers to be future pro-independence leaders: Francisco de Miranda, Alonso de Rojas, Pablo de Olavide, Hipólito Unanue and José Baquíjano; besides some others that, in due time, would become 'famous Argentinians'. ${ }^{29}$

How did this happen, according to the author? Basically through 'a key group of disseminators' of the ideas of the Radical Enlightenment. This group travelled to Europe and, he writes, not a few 'returned completely converted to radical ideas of basic human equality, popular sovereignty, universal toleration, and also, burning with resentment at the oppression exercised by the Spanish crown and its viceroys, utterly convinced of the merits of armed revolution as the requisite way to obtain their elevated new goals'. ${ }^{30}$ Among the disseminators of the Radical Enlightenment Israel includes not only Miranda and Baquíjano, already mentioned, but also Manuel Belgrano, Simón Rodríguez and Simón Bolívar. In the pages that follow, new names of representatives of "the politicized Spanish American Enlightenment' appear: among them, Antonio Nariño, Pedro Fermín de Vargas, Javier Eugenio de Santa Cruz y Espejo, Sebastián López Ruiz and Joaquín Alzamora. According to Israel, all of them participated in seditious meetings that, in his view, were part 'of a continent-wide intellectual ferment of great political and cultural significance. ${ }^{31}$ This apparently hyper-politicized situation would be reinforced by the movement that, he tells us, universities, bookshops and private parlours put in motion. This would explain 
that certain future leaders of the independence movements who did not travel to Europe were capable of acquiring what he calls 'a new Radical Enlightenment culture'. ${ }^{32}$

What can be said about this interpretation of the Spanish American Enlightenment? To begin with, it tends to establish a mechanic and anachronistic relationship between ideas and political practices (in this case, nothing less than revolutionary movements in search of independence). Secondly, a series of intellectuals and political leaders are attributed a series of readings and of radical political positions that are not only worth discussing in much more detail, but in some cases do not appear to have historiographic support. To take only one example, in the list that Israel gives of Spanish American radical leaders and intellectuals, nobody except probably Miranda can be said to have upheld 'universal toleration'. Besides, not one of the creoles enumerated by Israel (including Miranda) believed in something that can be defined as 'basic human equality', except in a very formal sense that had no consequence on their practical social notions and their political practice. As to the assertion that several of these same creoles were 'utterly convinced of the merits of armed revolution', we can only say that this is but one of the many examples of prolepsis throughout the chapter in question. Although, once again, Miranda is an exception. Throughout the chapter, this recurring anticipation of movements, processes and events that would take place many years after (in principle, the chapter closes in I792), is one of the many debatable consequences that derive from a view of history that consists in a zero sum game in which one of the contenders (Radical Enlightenment) is always superior, is always ahead, in terms of the most important values and principles of what we understand today as 'modernity'; among them, those that have to do with an open, non-confessional, secularized and tolerant society (that is, a kind of society that, it could be argued, does not exist even today in several Latin American countries).

If the French Counter-Enlightenment responded to a peculiar, very anti-Church and in some aspects very anti-religious Enlightenment, and if the Spanish Enlightenment was extremely moderate in religious issues, from where could a Spanish American Counter-Enlightenment emerge? The social conservatism of the Creole elites, the ubiquitous presence of the Church in the daily life of Spanish Americans, the control mechanisms that the metropolitan authorities had at their disposal 
(starting with the Inquisition), the negative consequences of these mechanisms regarding the creation of something that could be considered a public sphere, ${ }^{33}$ the scant amount of inhabitants in Spanish America that was able to read, the very limited success of the projects of University reform in the region, the fact that the philosophes were read to a good extent through its critics or in censored versions, the lack of translations of the vast majority of the books of the French Enlightenment, the attitude in Spain and its American dominions towards anything French after I 789 and, finally, the lack of a social and economic infrastructure that would permit the development and relative autonomy of a group that could be called 'intellectuals', are some of the reasons why historians should be very cautious when writing without qualifications about 'Enlightenment' and 'Counter-Enlightenment' in Spanish America. This being said and as the next two sections will show, some aspects of the Enlightenment and of what could be considered its CounterEnlightenment did have a place under the Spanish American sun.

\section{Counter-Enlightenment in Spanish America?}

The term 'Counter-Enlightenment' is even more problematic than 'Enlightenment', because, as mentioned, the former seems to depend on what we understand by the latter. If we view the Spanish Enlightenment as a moderate one and in consonance with very concrete objectives of the Crown, it could be inferred that some reactions against the expulsion of the Jesuits or against the diverse projects of political and cultural reform that ran throughout the eighteenth century were Counter-Enlightened, to the extent that they were reactions to 'Enlightened despotism'. In this sense, some authors have considered the famous I77 I Representation of the of the Mexico City council as an argument of the Counter-Enlightenment against the reforms of Carlos III. ${ }^{34}$ However, if we adopt a critical stance regarding the expression 'Enlightened despotism' in the Spanish case, it seems almost inevitable to accept that that many of the measures taken by Carlos III were not guided by an Enlightened spirit and that there were great differences between a certain notion of the Enlightenment and the raison d'état which oriented many of the reforms that this king sponsored during his long reign (I759-88). In this sense, the Representation of I77I, 
although it contained certain traditional elements, could hardly be considered a Counter-Enlightened document.

Francisco Sánchez-Blanco distinguishes what he calls verdadera Ilustración (true Enlightenment) from those utilitarian projects that served Carlos III to consolidate his absolutism. The author maintains that the true Enlightenment flourished from I730 to I760, until it started to vanish due to the attacks of certain intellectuals that were close to the new king. Sánchez Blanco, nonetheless, does not use the term 'Counter-Enlightenment' because he accepts the paramount importance of an economic and utilitarian Enlightenment that believed in progress and that affirmed that only a concentrated power would be able to order society in a way that would bring concrete public benefits for many Spaniards. ${ }^{35}$ This position regarding a Spanish utilitarian Enlightenment does not deny the fact that the Catholic nature of the Spanish and Spanish American Enlightenments makes it very difficult to talk of a Counter-Enlightenment in the Spanish-speaking world that comprises the religious and political domains. It is true that this difficulty almost evaporates once the Spanish liberal revolution and the Spanish American independence movements start at the end of the first decade of the nineteenth century. However, this is precisely the type of 'proleptic' approach that should be avoided.

The notion of Enlightenment in the mundo hispánico has developed in the last decades in reaction to an ingrained interpretation that not only viewed Spain as backward and conservative, but also as isolated from the exterior world..$^{36}$ By showing that in Spanish America there were authors in favour of reform and willing to confront conservative forces during the eighteenth century, a new generation of scholars has tried to show that there were 'modern' tendencies that entered in a dialectic tension with traditionalism. ${ }^{37}$ However, the confrontation between modernity and tradition does not coincide with certain specific intellectual groups, as Isabel Terán has shown after studying one of the many controversies among creole men of letters that took place throughout the century..$^{38}$ In consonance with the idea of a Catholic Enlightenment, the historian of science Elías Trabulse has argued that the 'movement' of the Enlightenment had penetrated in Spanish America between I730 and the independence period, albeit with an explicit Catholic imprint. ${ }^{39}$ More recently, Iván Escamilla has shown the need to reflect again on the concept of Enlightenment in Spanish America, avoiding simplistic causal interpretations and assuming the peculiar characteristics 
of a Catholic and to a good extent also ecclesiastical Enlightenment. For Escamilla, the movement should be understood in its own terms, unless we accept a homogeneous and therefore a-historic notion of the Enlightenment. ${ }^{40}$

Thus, the New Spaniard Juan José de Eguiara y Eguren (I696I763) defended the intelligence and value of several Spanish American thinkers, without hiding or trying to hide the traditionalism that characterized many of them. In I760 Eguiara published a critique of the Teatro Crítico of Jerónimo Feijóo (I676-I764), considered the most important of the Spanish pre-Enlightenment authors. The critique was written by the Cuban author Francisco Ignacio Cigala (I7I 2-?). Its main objective was to show the fallacies of modern philosophy and the intellectual vigour of scholasticism..$^{4 \mathrm{I}}$ The New Spaniard Benito Díaz de Gamarra (I745-I783), one of the most important eighteenthcentury philosophers in Spanish America, was a sponsor of educational reform in the universities of the viceroyalty and advocated the introduction of an eclectic philosophy to replace scholasticism. He also thought that the main objective of reform was to prepare students 'to defend the truths of our Catholic religion, to prepare them against atheism and the infamous disciples of Spinoza, Hobbes, Bayle and other pernicious materialists of this century'. ${ }^{22}$ These examples show how conservative the Spanish American Enlightenment could be while at the same time it attempted a reform of philosophy, literature and the sciences. Likewise, the style and content of sermons went through a considerable transformation; they became more argumentative and tried to conciliate reason with tradition. The tensions and contradictions that characterize eighteenth-century Spanish American thought is aptly illustrated by the previously mentioned Gamarra, who defended modern philosophical theories of knowledge but also published a sermon that eulogized an eremite devoted to pure contemplation and the mortification of the body. ${ }^{43}$

Some authors have coined the term patriotismo criollo to explain this seemingly ambivalent attitude. The response of the Jesuit Francisco Xavier Clavijero (I73I-I787) to European thinkers like Buffon, De Pauw or Raynal can be understood from this perspective as an effort to defend the New World from the calumnies of the Old. ${ }^{44}$ However, other authors have suggested that eighteenth-century Spanish American texts can be read differently. Jorge Cañizares-Esguerra, for example, 
maintains that Clavijero defended the humanist tradition vis-à-vis the philosophical speculation that characterized medieval thought. The conscious search for a balance between reason and tradition on the part of Spanish American thinkers can be viewed as a way to include some of the more outspoken authors associated with the European Enlightenment. 45

A critical opposition to the European Enlightenment can be perceived in the articles published in several newspapers during the last quarter of the eighteenth century, such as those written by several creole authors reflecting on Linnaeus' famous botanical classification. ${ }^{46}$ Several of these articles were critical of Linnaeus categories because, in their view, they ignored the importance of the countless species that existed in the American continent. José Antonio Alzate y Ramírez (I737-I799) was evidently an Enlightened author, in the sense that he actively participated in newspapers and in several literary debates, besides trying to renovate the literary landscape of New Spain. Nonetheless, as Rafael Moreno has suggested, Alzate often subordinated science, philosophy or truth to his 'patriotic' objectives, which included both the Spanish fatherland and America. ${ }^{47}$ Likewise, in New Granada, José Celestino Mutis (I732-I 808) created a 'new method' of botanical classification while trying to establish a dialogue with the scientific renovation that was taking place in Europe.$^{48}$ Like other scholars in this region of the Spanish Empire in America, Mutis supported educational reforms and promoted the creation of a community that, according to Renán Silva, can be called 'enlightened' more for its cultural practices than for its ideas. Though conservative in religious respect, they sometimes identified with French Enlightened thinkers and were included among the philosophes by their critics. ${ }^{49}$

\section{Counter-Enlightenment as Anti-Philosophie in Spanish America}

In Spanish America, a considerable part of the reaction against an Enlightenment that was perceived as foreign was expressed in terms of censorship. The inquisitorial prohibition of isolated works turned into a general prohibition of the whole oeuvre of several authors, mainly of French origin, resulting in the Index of I790. Where previously these 
prohibitions had been mostly directed against Protestant theologians, they were now directed against Enlightened philosophers, who were regarded as the new heretics. The prohibitions were based on attitudes that can be viewed as Counter-Enlightened. Consider for instance the detailed censorship of Raynal's Histoire philosophique et politique, written for the Inquisition of Mexico City by the friar José Manuel Rodríguez (active I754-I773), a Franciscan theologian born in Cuba who had a reputation as a 'modern' preacher because of his neoclassical style. He was convinced that Raynal (whom he did not mention by name) was one of the new philosophes, 'the so-called esprits forts... who wished to break down [the State and the Church] from their foundations'. Despite this general disqualification, Rodríguez made a very detailed critique, trying to undermine the main points of the book, particularly its opinions on liberty, religion and sovereignty..$^{50}$

Though these pareceres or censorship opinions were supposed to be read only by the inquisitors, they were widely disseminated through the inquisitorial prohibitions that were read in the churches. An edict of I778 against the book L'An deux mille quatre cent quarante, by Louis Sébastien Mercier, affirmed that it was

in all substance and sentiments...impious, reckless and blasphemous, promoter of Deism, very slanderous against the Supreme Pontiff, Holy Fathers, Clergy, Religious Orders and all the ecclesiastical ranks, defamatory of the respectful memory of many kings, singularly of those of Spain and of the Royal House of Bourbon, with no respect for the Laws and bringing injury to the magistrates; disturbing society and exhorting sedition, independence and debauchery through affected and fraudulent eloquence and with vehement and furious invectives.

According to this parecer, the anonymous author (the Inquisition did not know it was written by Mercier), was 'an implacable enemy of the State and the Christian Religion' whose aim seemed to be 'not only to ruin all revealed Religion, but also...to destroy...the kingdoms and monarchies'.$^{51}$ The long list of prohibitions drafted by the inquisitors suggests that they intended not only to ban particular works, but also to reject Enlightened literature in general.

Although censorship imposed serious limits on the publication of certain works, a select group of Spanish Americans was in fact involved 
in reading and even expressing Enlightened opinions. This public debate is lost from view if we limit our analysis to the way in which the Spanish authorities tried to inhibit the dissemination of specific works. In France, controversial works were published clandestinely or abroad in order to avoid print restrictions and censorship, as was the case with the Encyclopédie..$^{52}$ In Spanish America, these options were not available. However, the circulation of forbidden works was very common among certain groups, as attested by the presence of these books in the libraries of functionaries, priests and scholars in Mexico City and Lima. Some of them held permissions to read prohibited works issued by the Inquisitor-General of Spain, though some authors were forbidden even to those who had these permissions. ${ }^{53}$ It is therefore not difficult to understand why inquisitorial censorship needed to be reinforced by arguments that were expressed in sermons, newspaper articles, prologues to books and other publications, as well as other means. ${ }^{54}$ The general discourse was ostensibly directed against foreign authors but its real target was the Spanish American community of readers.

Since the I76os the French Counter-Enlightenment was also present in Spanish America, thanks to the translation and publication of books written by anti-philosophes, such as El oráculo de los nuevos filósofos by Claude-Marie Guyon (I760), Los errores de Voltaire by Claude-Adrien Nonnotte (I77I) and El deísmo refutado por sí mismo by Nicolas-Sylvestre Bergier (I777). Books like these inspired friar Fernando de Ceballos (I732-I802) to write La falsa filosofía, a sixvolume work that best illustrates this new anti-philosophic genre. ${ }^{55}$ As McMahon has shown, such writings had unintended and even paradoxical consequences: they encouraged the curiosity of many readers regarding the original authors as well as a critique of their refuters. An officer at the Mexican mint, for example, declared that he had bought one of these books, El deísmo refutado por sí mismo by Bergier, and 'stimulated by curiosity' began to read it. However, he soon realized that the arguments of the author were more effective than the refuter's, so he stopped reading and sold it. ${ }^{6}$ Documents like this one, which can be found without much difficulty in the abundant archives of the Mexican Inquisition, suggest that some of the public and not so public debates about the philosophes were based on information provided by such refutations. ${ }^{57}$

Information from other parts of Spanish America suggests a similar process. Santiago Urquizu, the son of a Peruvian oídor (judge), in 
I 782 denounced himself to the Inquisition of Lima for having read several prohibited works. According to his confession, he began trying to read them through the refutations, but the more he read, the more he wanted to read the original authors. As a compulsive book buyer, he found ways to obtain the books of Voltaire, d'Holbach and many others..$^{8}$ Guyon's Oráculo de los nuevos filósofos, intended mainly to disqualify Voltaire's arguments, was particularly well-known in Spanish America. At the end of the eighteenth century, after having received a particular complaint against the book, the Mexican Inquisition handed it over to the censors. One of them stated that the work was 'very good' but warned: 'wandering into everybody's hands, and mainly those of traders, it can be very harmful and scandalous, because not everybody is equally able to penetrate the force of the refutation, especially when [the author] includes almost literally the speeches of Voltaire with all their persuasive flattery'. ${ }^{9}$

A variation of the anti-philosophical genre was the satire, which, however, was not always suitable for publication. In I776, Pablo de Olavide (I725-I803), a royal official born in Peru who was part of the Enlightened circle of the Count of Aranda and a well-known public servant for the Crown, was arrested by the Inquisition in Madrid accused of impiety, among several other charges. Almost immediately a satirical manuscript against him appeared, with the title The Enlightened Century (El Siglo Ilustrado), in which he was nicknamed 'Guindo Cerezo'. The anonymous author mockingly praised the new 'Enlightened' thinkers (ilustrados in Spanish) who despised the Spanish tradition and were too eager to import ideas and books from France. Initially, the Inquisition did not act against the copies of this manuscript, which circulated both in Spain and in America. But finally it decided to ban it in 788 because some readers could consider the praise as serious. However, some copies of the text remained in Spanish and Mexican libraries despite the order to return the book in order to be burned. ${ }^{60}$

Another anti-philosophical book, written by a now repentant Olavide, became a bestseller. First published in 1797, El Evangelio en triunfo circulated all throughout the mundo hispánico as an anonymous work, although everybody knew who its author was. Though it had some stylistic similarities with works of anti-philosophie, it was also an epistolary novel that tried to create a sentimental empathy with its readers. In this, and in its way of turning the French Revolution into a 
series of horrifying and despicable events, Olavide's book was original. It was also original in its recounting of the story of a philosopher who was once critical of religion, but had seen the light of God at the end of his days. This epiphany leads him to deprecate the philosophical arguments he once used against his religion. One of the main conclusions of the book is very simple: to attain happiness, there is no need for 'lights', understood as reason, because faith suffices. ${ }^{6 r}$

According to Peer Schmidt, Spanish American churchmen often replicated Counter-Enlightened arguments in their sermons. ${ }^{62}$ One of them was José Fernández de Uribe (I742-I796), who criticized the 'false lights' of the century in a sermon on the Virgin of Guadalupe in I777. At the same time, Iván Escamilla has defended Uribe's thinking as representative of the Spanish-American Catholic Enlightenment, mainly for his utilitarian ideas and educational projects. ${ }^{63}$ How do we deal with such disagreement? The problem ultimately takes us back to the unsolved question as to what, exactly, the Enlightenment is. We should note that Uribe's work was published posthumously in I80I, when the Enlightenment was practically over. Again, as noted, the term 'Catholic Enlightenment' should be used cautiously; in this case it is limited to the utilitarian and educational fields, two aspects that were part and parcel of both the Spanish and Spanish American Enlightenments.

In terms of political ideas, a conservative moment held sway as social unrest spread in some parts of Spanish America during the last decades of the eighteenth century. In New Granada, in reaction to the comunero rebellion of I78I, the Capuchin Joaquín de Finestrad (I744-I8II) developed what Renán Silva has called a 'pedagogy of vassalage'. Finestrad saw a direct link between Enlightened political speculation and rebellion. ${ }^{64}$ Some years later, Manuel del Socorro (I758-I8I9) published an original criticism of the French Revolution in his Papel periódico de Santa Fé. Del Socorro was an active promoter of newspapers and has been considered a representative of the Enlightenment in New Granada; however, he did not hesitate to support the idea that 'the lights' would lead to catastrophe when they deviated from religion. ${ }^{65}$ Several authors in other parts of Spanish America would retake these notions after the political crisis of I 808 turned everything upside-down in the whole mundo hispánico as a consequence of the invasion in that year of the Iberian peninsula by Napoleon's army. In New Spain, these notions cropped up in the sermons of José Mariano Beristáin y Souza, 
Manuel de la Bárcena, Antonio Pérez and Patricio Fernández de Uribe, among others.

The French Revolution, the war between Spain and the French Republic, the Haitian Revolution and, some years later, the beginning of the revolutionary movements in Spanish America gave many theologians and intellectuals ample material to develop an anti-revolutionary literature. The link that many established between the Enlightenment and the French Revolution contributed to the bleak image of Enlightened thinkers; in an uncritical way, they were all considered revolutionaries. The Enlightenment was viewed ex post facto as a period that instilled revolutionary thoughts and attitudes in society in general. Once the crisis hispánica began in I 808, fear of anything that had an 'Enlightened' flavour became the norm in the Spanish-speaking world among the defenders of the Establishment. A new model began to take form: that of Abbé Barruel and his unflinching idea that the Enlightenment was the mother of all the errors of the eighteenth century. ${ }^{66}$

Many of the authors mentioned above were respectable scholars. In some cases, they have been identified as representatives of a Catholic Enlightenment. But can we still talk in these terms when these 'Enlightened' authors assumed attitudes that were against reconciling reason and tradition, and when they ended up affirming that the latter was the only dike that could contain the dangerous flux of ideas arising from Enlightened pride and arrogance? Curiously, at the same time that a more Counter-Enlightened literature developed, what could be considered signs of weakness on the side of the defenders of tradition may be detected. Starting with the de facto revolution of the press that started in Cadiz in I808, the traditionalists realize that for the first time they had to publicly defend their positions against their antagonists. The decree issued by the Cortes that officially established freedom of the press in I8Io changed even more the whole scenario in the mundo hispánico for the critics of the Enlightenment.

When the previously mentioned Beristáin y Souza (I756-I8I7) published the Biblioteca Hispano Americana Septentrional in I8I6, a continuation of the one started by Eguiara y Eguren in 1755 , he recognized that the majority of the works included in it did not correspond to what intellectuals in Europe had written during the eighteenth century. There were too many sermons and too few philosophical tracts. However, the latter were enough in his view to show the vigour of 
Spanish American thinkers as intellectual shields against the threats that century had brought along with it:

I well know that for the very delicate taste of the learned men of this century of irreligion, debauchery and materialism, except for a dozen items of this Library, all the others are worthy straw for the flames, for they are monuments of the fanaticism and superstition of...the Aristotelian friars... in Spanish America there are still worthy disciples of the Spaniard [i.e. Spanish thinkers] of the sixteenth century. ${ }^{67}$

It was precisely these devotees that made Beristáin y Souza proud. One censor, Matías de Monteagudo, expressed his approval by saying that the Biblioteca was a reply to the calumnies of the Raynals, De Pauws, Robertsons and all those European thinkers who had insulted the Indies. Now they would have to remain silent. For Monteagudo, the Biblioteca represented the triumph of evangelical principles over philosophy. The philosophers pretended to dogmatize about earthly happiness, but they were unable to even glimpse at it because they had destroyed half the world with their chimerical projects. ${ }^{68}$

As we have tried to show in the preceding pages, the ambiguous nature of the Spanish American Enlightenment is undeniable. At times, it is practically impossible to draw clear lines among Enlightenment, Catholic Enlightenment and Counter-Enlightenment. The fact that this was much easier to do once the crisis hispánica began, does not diminish the ambiguity in question. What from a certain angle could be considered as Enlightened in the Spanish-speaking world, looked at from another perspective could be considered a critique of some of the main traits of the Enlightenment, and in certain cases even as an integral critique of the Enlightenment as a cultural and intellectual movement.

\section{Concluding Remarks}

We do not know if Renán Silva's suggestion that the Enlightenment in New Granada was un corto veranillo de San Martín (a few warm days in the middle of autumn) can be extended to the rest of Spanish America. ${ }^{69}$ In any case, the fact that a historian like him, a recognized expert on the Enlightenment in the region, uses that expression should alert us to what sometimes could be considered the inadvertent 
transplant, adoption and application of certain historiographic categories. At present, there does not seem to be a consensus regarding the nature of either the Spanish American Enlightenment or the Spanish American Counter-Enlightenment. Returning to Brian Hamnett's book on the Iberian Enlightenments, our view coincides with his regarding the moderation of the Spanish and Spanish American Enlightenments, in putting into question the pertinence of the category 'Catholic Enlightenment', and in casting serious doubts on talking of a political Enlightenment in the Hispanic world. We differ with him, however, regarding the Spanish American Counter-Enlightenment.

Hamnett's book devotes one chapter to the Counter-Enlightenment and only six pages to the Counter-Enlightenment in Spanish America. It can be inferred from these pages that what has been written on the confrontation between the Enlightenment and what could be called 'anti-Enlightenment' is limited to New Spain and Peru. ${ }^{70}$ The fact that Hamnett devotes these pages to the post-I 8 I o period in both viceroyalties, when the new political circumstances created by the crisis hispánica had merged Enlightenment with liberalism in the Peninsula and with the search for independence in Spanish America, implicitly denies or at least diminishes the entity of the notion of a Counter-Enlightenment in the region in the last decades of eighteenth century. As we have tried to show in this article, there was an active French Counter-Enlightenment in the region during the second half of that century (the translation into Spanish of several counter-Enlightened books gives an idea of the level of this activity). This profoundly religious and profoundly conservative thought was very critical of principles that were considered 'Enlightened' not only by the critics of the Enlightenment. Again, we must distrust absolute categories, especially when we are talking about Spanish America and the Enlightenment (and therefore, about the Spanish American Counter-Enlightenment).

To sum up, the moderation of the Enlightenment in the Hispanic world makes it difficult to flesh out a Counter-Enlightenment. This difficulty only subsides after I808 or I8Io, once the crisis hispánica had got under way and liberal principles began to predominate in the Peninsula and the discourse of autonomy and independence started its expansion in Spanish America. Nevertheless, this fact does not deny the existence of a previous, important and protracted CounterEnlightenment. As we have tried to show, the 'inconclusive' character of the Spanish American Enlightenment is also the consequence of 
the state of flux that contemporary Western academia is going through regarding the contents and connotations of the Enlightenment in general. More specifically, we think that considering the French CounterEnlightenment as a sort of model or parameter is clearly misleading because the Spanish and Spanish American Enlightenments had none of the anti-Church and anti-religious character of the French case.

In significant aspects, the most well-known of the new interpretations of the Enlightenment, that of Jonathan Israel, has received a fair amount of criticism. His view of the Enlightenment as eminently radical seems to close the door in several respects to an Enlightenment like the one that clearly predominated in Spain and in its American dominions. However, as mentioned, in his last book on the topic Israel proposes a vibrant and radical Spanish American Enlightenment, which supposedly was directly connected with the independence movements that began in I 8Io. If Israel's 'radicalism' has been put into question by several experts on the European Enlightenment(s), an even more sceptical reception regarding Spanish America is in order. The adoption of a critical stance and some of the arguments presented in this article may contribute to encourage a debate that we consider timely and important, not only for the region in particular but for the discussion of the Enlightenment as a whole.

To conclude, it appears that the word 'ambiguous' we have used to describe the Spanish American Enlightenment is not only an appropriate epithet, but also one of its constitutive qualities. In our view, this characterization should spur scholars in and beyond Latin America to keep on ruminating on what the terms 'Enlightenment' and 'CounterEnlightenment' mean when they are applied to Spanish America.

\section{Notes}

I A good overview of the main critics of the Enlightenment since the eighteenth to the end of the twentieth century is Graeme Garrard, Counter Enlightenments. From the Eighteenth Century to the Present) (Abingdon, 2006). Unfortunately, this book was published when the confrontation alluded here was just starting.

2 Jonathan Israel, Radical Enlightenment. Philosophy and the Making of Modernity, I650-I750 (Oxford, 200I); the other two volumes are Enlightenment Contested. Philosophy, Modernity, and the Emancipation 
of Man, I670-I752 (Oxford, 2006) and Democratic Enlightenment. Philosophy, Revolution, and Human Rights, I750-I790 (Oxford, 2012). In total, this new interpretation of the Enlightenment consists of more than 2,500 pages.

3 Radical Enlightenment, I I.

4 Ibid., I2.

5 Democratic Enlightenment, I2.

6 Ibid., I3.

7 Democratic Enlightenment, I6 (our italics). According to Israel, all the great French revolutionaries (Mirabeau, Sieyès, Brissot, Condorcet, Bailly and Cloots, among them) took their egalitarian and democratic ideas from the Radical Enlightenment.

8 'The Counter-Enlightenment', in The Proper Study of Mankind. An Anthology of Essays (New York, I998), 268.

9 Ibid., 23.

Io Ibid., 26.

I I Dictionary of the History of Ideas, Philip P. Wiener (ed.) (New York, I973; 5 vols.). The entry is in vol. II, IOO-I I2.

I 2 'Isaiah Berlin and the Counter-Enlightenment: A Reassessment', in 'Persistent Enlightenment': https://persistentenlightenment.com/2014/02/05/ c-e6/ (posted on February 5, 2014).

I3 'The Counter Enlightenment', 263.

I4 The Anti-Enlightenment Tradition (New Haven, 20I0), 4I I.

I 5 Darrin M. McMahon, Enemies of the Enlightenment (The French CounterEnlightenment and the Making of Modernity) (New York, 200I), Io.

I6 Sometimes not even that: for example, Roy S. Porter and Mikulás Teich (eds), The Enlightenment in National Context (Cambridge, I98I) considered twelve national cases, but did not include Spain.

I7 Francisco Sánchez-Blanco recognizes that there was an Ilustración in Spain since very early in the eighteenth century and that there is no denying its native character; at the same time, he underlines its moderation and traditionalism, especially under Carlos III, considered the most enlightened of Spanish kings. Sánchez-Blanco has written several books on the Spanish Enlightenment, among them, El absolutismo y las luces en el reinado de Carlos III (Madrid, 2002) and La Ilustración goyesca (Madrid, 2007). An effort to reinterpret some aspects of the Spanish Enlightenment from an imperial perspective is Gabriel B. Paquette, Enlightenment, Governance, and Reform in Spain and its Empire, I759-I808 (Basingstoke, 2008). 
I8 Jesús Astigarraga, The Spanish Enlightenment Revisited (Oxford, 2015), I 3 and I5.

I9 Brian Hamnett, The Enlightenment in Iberia and Ibero-America (Scarborough, 2017).

20 Ibid., Io.

2 I Roberto Breña, El primer liberalismo español y los procesos de emancipación de América (Una revisión historiográfica del liberalismo hispánico) (Mexico City, 2006), I75-89.

22 Arthur P. Whitaker, 'The dual role of Latin America in the Enlightenment', Latin America and the Enlightenment, Whitaker (ed.) (Ithaca, I96I; original edition I942), 3-2 I. The last article included in this book, by Charles C. Griffin, 'The Enlightenment and Latin American independence', I I9-43, is much more cautious regarding the relationship between Enlightenment and Independence than some contemporary authors.

23 José Carlos Chiaramonte, Prologue to El pensamiento de la Ilustración (Economía y sociedad iberoamericanas en el siglo XVIII) (Caracas, I979), xvii (all translations to English are ours). Chiaramonte's doubts regarding the entity of the Enlightenment in Spain and Spanish America, and more specifically regarding the Ilustración católica (Catholic Enlightenment), did not diminish with the passing of time. See his prologue to the second edition of La Ilustración en el Río de la Plata (Cultura eclesiástica y cultura laica durante el virreinato) (Buenos Aires, 2007), 9-I5.

24 Israel, Democratic Enlightenment, Chapter I8, 504-34.

25 Ibid., chapter I4, 374-4IO.

26 Ibid., 505 .

27 Ibid., 508.

28 The last two citations in ibid., 5 I7.

29 Ibid., 5I7. Among these 'famous Argentinians', José de San Martín and Manuel Belgrano are the best options. However, these two well-known leaders of the revolution in Río de la Plata and other parts of America (in the case of San Martín), barely respond to Israel's characterization of the Radical Enlightenment.

30 Ibid. 5I7. At some point (5I8), Israel defines the Spanish American Enlightenment as 'subversive'. As Gabriel Paquette writes in Enlightenment, Governance, and Reform, the Spanish Enlightenment was not subversive, but developed within and in support of the established order (I 5). Paquette insists on this issue in 'The reform of the Spanish empire in the age of Enlightenment', in Astigarraga, The Spanish Enlightenment Revisited, 
I49-67, specifically I6o. In our view, exactly the same can be said of the Spanish American Enlightenment.

3I Ibid., 5I9.

32 Ibid., 534; the two names mentioned by the author at the end of the chapter are Jaime de Zudañez and Bernardo de Monteagudo. The contribution of the Spanish American universities to the development of revolutionary leaders is not easy to reconcile with various passages devoted to these academic institutions throughout the chapter.

33 On the relationship between public opinion and censorship, see Gabriel Torres Puga, Opinión pública y censura en Nueva España. Indicios de un silencio imposible, I767-I794 (Mexico City, 2010).

34 Peer Schmidt, "Contra "la falsa filosofía": La Contra Ilustración y la crítica al reformismo borbónico en Nueva España', in Karl Kohut and Sonia V. Rose (eds.), La formación de la cultura virreinal, tomo III (El siglo XVIII), (Madrid-Frankfurt, 2006), 233-36.

35 Sánchez-Blanco, El absolutismo y las luces en el reinado de Carlos III, I04.

36 The classic example is Jean Sarrailh, La España ilustrada del siglo XVIII (Mexico City, I957).

37 The first and most audacious of these interpretations was Pablo González Casanova, El misoneísmo y la modernidad cristiana en el siglo XVIII (Mexico City, I948).

38 Isabel Terán, Orígenes de la crítica literaria en México. La polémica entre Alzate y Larrañaga (Mexico City, 2009), 28-37.

39 See his book Francisco Xavier Gamboa: un político criollo en la Ilustración mexicana (Mexico City, I985), Io-I I.

40 'La Iglesia y los orígenes de la Ilustración novohispana', in María del Pilar Martínez (ed.), La Iglesia en Nueva España. Problemas y perspectivas de investigación (Mexico City, 2010), I I2.

4I Mauricio Beuchot, La ciencia y la filosofía modernas en la carta contra Feijóo de Francisco Ignacio Cigala (Mexico City, I993), 78, n. I.

42 Dorothy Tanck, La Ilustración y la educación en la Nueva España (Mexico City, I985), 98.

43 Carlos Herrejón, Del sermón al discurso cívico (Mexico City, 2003), I I I. This book is a detailed research on the evolution of the sermon in New Spain throughout the eighteenth century.

44 Regarding patriotismo criollo, the seminal works are David Brading's Los orígenes del nacionalismo mexicano (Mexico, I973) and Orbe indiano (De 
la monarquía católica a la república criolla, I492-1867) (Mexico City, I993). The expression, once accepted at face value, has received a much more sceptical reception in the last years.

45 How to Write the History of the New World (Stanford, I99I). See also Cañizares-Esguerra, 'La historiografía nueva', in Nancy Vogeley and Manuel Ramos (eds.), Historia de la literatura mexicana (Mexico City, 20II) vol. 3, 405-I3.

46 Roberto Moreno, Linneo en México (Las controversias sobre el sistema binario sexual, I788-I798) (Mexico City, I989).

47 Rafael Moreno, La filosofía de la Ilustración en México y otros escritos (Mexico City, 2000), I24-25.

48 Daniela Bleichmar, 'Painting as Exploration: Visualizing Nature in Eighteenth-Century Colonial Science', Colonial Latin American Review, vol. I5, n. I, June 2006, 8I-I04.

49 Renán Silva, Los ilustrados de Nueva Granada. I760-1808. Genealogía de una comunidad de interpretación (Bogotá, 2002), 20-2.

50 AGN, Inquisición, II40, exp. I. José Manuel Rodríguez is studied in Herrejón, Del sermón al discurso cívico, 77-8I.

5I Edict of the Mexican Inquisition reproducing an edict of the General Inquisitor Felipe Bertrán. July 4th, I778. AGN, Edictos de Inquisición, I.

52 Robert Darnton, Business of Enlightenment: A Publishing History of the Encyclopédie: $1775-1800$ (Harvard, I979).

53 Monelisa Pérez Marchand, Dos etapas ideológicas del siglo XVIII en México (Mexico City, 1945), 99-III. Pedro Guibovich, Lecturas Prohibidas. La censura inquisitorial en el Perú tardío colonial (Lima, 20I3); see particularly the chapter entitled 'Bibliotecas y lectores', 83-I I 2.

54 The impact of censorship cannot be ignored; however, self-censorship also played a very important role.

55 In New Spain, all of these books were sold in Mexico City's principal bookshops and even announced in the Gazeta de México in order to make deliveries to the provinces.

56 Relation of the cause against Juan Pablo Catadiano, Archivo Histórico Nacional de Madrid, Inquisición I732-I.

57 Torres Puga, Opinión pública y censura, 498-50 I.

58 Guibovich, Lecturas prohibidas, I08-I2.

59 File on the denunciation against the Oráculo de los filósofos. AGN, Inquisición, I349, exp. I (I794-I806). 
6o Michel Dubuis and María Isabel Terán, introductory study to Justo Vera de la Ventosa (pseud.), El Siglo Ilustrado. Vida de Don Guindo Cerezo (Mexico City, 2010).

6i El Evangelio en triunfo. Historia de un filósofo desengañado (Valencia, I797I798; 2 vols.). On the romantic and fictional elements of the book, see Gérard Dufour, 'Elementos novelescos de El Evangelio en triunfo de Olavide', Anales de Literatura Española, n. I I, I985, I07-I I5. According to Dufour (I I5), there were fifteen editions of this book between I797 and I848.

62 Schmidt, "Contra "la falsa filosofía", 244.

63 José Patricio Fernández de Uribe (1742-1796). El cabildo eclesiástico de México ante el Estado borbónico (Mexico City, I999).

64 Renán Silva, La Ilustración en el virreinato de Nueva Granada (Medellín, 2005), 205.

65 Andrés Felipe Serrato, 'Un ilustrado ante la Revolución Francesa', en Iván Vicente Padilla (ed.), Sociedad y cultura en la obra de Manuel de Socorro Rodríguez de la Victoria (Bogotá, 2012), I27-62.

66 In the Mexican edition, friar Ramón Casaus, professor at the University in Mexico City and Bishop of Guatemala, referred to that century as 'tainted with plenty of impieties of hellish and sanguinary writers'. Barruel, Historia del clero en el tiempo de la revolución francesa (Mexico City, I800), I.

67 José Mariano Beristáin y Souza, Biblioteca Hispano-Americana Septentrional (Mexico City I8I6); reprinted in I980-I98I, 3 vols., p. xvi, vol. I (our translation).

68 Ibid., xxi.

69 Renán Silva, 'Del mecenazgo al vacío. Los ilustrados de Nueva Granada como intelectuales modernos', in Kohut and Rose (eds.), La formación de la cultura virreinal, 538.

70 Hamnett overlooked the book by José Carlos Chiaramonte on the Enlightenment in Río de la Plata (see note 23). In fact, this book coincides with several of Hamnett's contentions about the Iberian Enlightenments and some of ours about the Spanish American Counter-Enlightenment. Hamnett's book is a very important contribution to the debate we are trying to foster with this article and other texts; see for example Roberto Breña, 'El debate actual sobre la Ilustración y la América española (Discutiendo a Jonathan Israel)', Revista de Occidente, n. 445, June 20 I8, 39-49. On Hamnett's book, see the review by Breña in Historia Mexicana, n. 277, vol. LXX (July-September 2020); online version: https://historiamexicana. colmex.mx/index.php/RHM/article/view/3783/373 I. 


\section{About the Authors}

Roberto Breña has a $\mathrm{PhD}$ in political science from the Universidad Complutense in Madrid, Spain. He is professor and researcher at the Centro de Estudios Internacionales of El Colegio de México. His main academic interests regard liberalism in the Hispanic world, the Atlantic Revolutions, intellectual history and the historiography of the Age of Revolutions. He is the author of El primer liberalismo español y los procesos de emancipación de América, I808-I824 (Colmex, 2006) and El imperio de las circunstancias (Marcial Pons/Colmex, 20I2); the latter is a critical overview of the Spanish liberal revolution and the Spanish American independence movements. He is also the editor of two books on this period of Western political and intellectual history. He has been visiting professor at universities in the United States, Canada, Spain and France. E-mail: rbrena@ colmex.mx

Gabriel Torres Puga has a PhD in history from El Colegio de México. $\mathrm{He}$ is professor and researcher at the Centro de Estudios Históricos of El Colegio de México; for many years he has also given courses at the Universidad Nacional Autónoma de México (UNAM). His work focuses on political control, judicial practices and censorship in the eighteenth-century Spanish speaking world, as well as on the history of the Inquisition in Spanish America. He is particularly interested in the transformation of public opinion and censorship, as well as in the diverse manifestations of criticism and dissent in the public and private spheres in the mundo hispánico during the eighteenth century. $\mathrm{He}$ is the author of Los últimos años de la Inquisición en la Nueva España (M.A. Porrúa, 2004) and Opinión pública y censura en Nueva España. Indicios de un silencio imposible I767-I795 (Colmex, 20I0). E-mail: gtorres@colmex.mx 